\title{
MÝTUS ČESKÉ HUDEBNÍ EMIGRACE Z POHLEDU DLABAČOVA SLOVNÍKU
}

Migrace hudebníků pocházejících ze zemí koruny české v průběhu 18. století patří mezi jisté stálice badatelského zájmu zejména české muzikologické školy. Toto téma bývalo studováno pod poněkud anachronickým pojmem tzv. české hudební emigrace, a to nejen ve vztahu ke zrodu mannheimské školy. ${ }^{1}$ Novodobější práce, zaměřené jak na migraci ze všeobecného pohledu, ${ }^{2}$ tak ve vztahu ke konkrétním destinacím ${ }^{3}$ nebo daným hudebníkům, ${ }^{4}$ se snaží o hlubší kontextualizaci problému a zamýšlejí se také nad relevantností pojmu emigrace jako takové. ${ }^{5}$

1 HELFERT, Vladimír. Jiři Benda: Přispěvek k problému České hudebni emigrace. Brno: Filosofická fakulta, I. sv., 1929, II. sv., 1934.

PILKOVÁ, Zdeňka. Zur Frage der Musiker aus böhmischen Ländern, die im Ausland wirkten, 1740-1810. In Telemanniana e talia musicologica: Festschrift für Günter Fleischhauer zum 65. Geburtstag. Dieter Gutknecht - Hartmut Krones - Friedrich Zschoch (eds.). Oschersleben: Ziethen, 1995, s. 215-220; PILKOVÁ, Z. Doba osvícenského absolutismu (17401810). In Hudba v českých dějinách. Jaromír Černý - Vladimír Lébl - Jan Kouba et al. (eds.), 2. dopl. vyd. Praha: Supraphon, 1989, s. 211-284.

PILKOVÁ, Z. Zelenkas Zeitgenossen und Nachfolger aus Nordböhmen in der Dresdner Hofkapelle. In Zelenka-Studien II, 1997, s. 487-492; Táž. Böhmische Musiker am Dresdner Hof zur Zeit Zelenkas. In Zelenka-Studien I, 1993, s. 55-64; Táž. Hudebníci z českých zemí v 18. století na drážd’anském dvoře. Opus musicum, 1992, roč. 22, č. 2, s. 51-57.

BAČVAROVÁ, Radmila. Mozartův pařižský přítel a editor: Český trubač František Josef Hejna. Hudebni véda, 1991, roč. 28, č. 4, s. 308-313; BORKOVÁ, Alena. K problematice české emigrace 18. století - J. Vaňhal. Opus musicum, 1971, roč. 3, č. 9-10, s. 285-291; FREEMAN, Daniel E. Josef Mysliveček, ,Il boemo": the man and his music. Sterling Heights, Michigan: Harmonie Park Press, 2009; FREEMANOVÁ, Michaela. Provincia germanica řádu milosrdných bratř́i. $\mathrm{K}$ pohybu hudebníků v českých zemích a stř̌ední Evropě 18. a 19. století. Hudební věda, 1998, roč. 35, č. 2, s. 171-174; KABELKOVÁ, Markéta. Wenzel Johann Tomaschek, nebo Václav Jan Tomášek? - Německy mluvící Čech aneb život na hranici dvou jazyků. Hudební věda, 2009, roč. 46, č. 4, s. 341-354; MACEK, Petr. František Xaver Richter 1709-1789. Holešov, Město Holešov: Knihovnička Holešovska sv. 19, 2009; PEČMAN, Rudolf. Josef Mysliveček. Praha: Editio Supraphon, 1981. 
Pojem české hudební emigrace byl tradičně použiván pro označení všech hudebníků pocházejících z českých zemí a někdy dokonce i jejich potomků narozených již jinde, kteří toto teritorium z různých důvodů opustili. Nejčastěji je pak termín spojován s migrační vlnou v průběhu 18. století. Tento termín je však problematický hned z více důvodů. Již slovo „emigrace“ je v daném kontextu a časoprostoru zcela anachronické a tedy nevhodné. Pilková vysvětluje, že „emigraci“ je v tomto smyslu nutné chápat v jejím moderním významu a kontextu, jelikož dobově by se jako emigrace dalo chápat i překročení hranic panství, které bylo bez souhlasu vrchnosti porušením práva. ${ }^{6}$ Přidržujíc se moderního významu slova pak Pilková za emigraci nepovažuje odchod do hlavního města, tj. Vídně, protože neznamenalo překročení státních hranic. Stejnou logikou věci by však neměl být za emigraci považován ani odchod do jiných částí habsburského soustátí, jako např. severní Itálie, což navrhuje Pečman s ohledem na Myslivečkovy cesty po Itálii. ${ }^{7}$

S ohledem na fenomén české hudební emigrace však nevzbuzuje otazníky pouze slovo emigrace, ale i jeho atribut českosti. Ne vždy totiž pouhá jména hudebníků nebo i studium pramenů umožňují určit jejich národnost. Pilková tak navrhuje použití termínu „hudebník pocházející z českých zemí, který vztahuje na hudebníky s ohledem na jejich místo narození, nikoli však na národnost. Takový př́istup si vynutily zejména studie o saské kurfiřtské kapele, v níž působilo množství hudebníků ze severních Čech, oblasti s velkou hustotou německého osídlení. Určení německé či české národnosti u instrumentalistů, kteří se v pramenech vyskytují jen zřídka, by totiž nebylo objektivně možné. Ve svých pracích věnovaných obecně migraci hudebníků $\mathrm{v} 18$. století, které se zatím jako jediná v takovém rozsahu věnovala, pak Pilková používá ponejvíce dat z Dlabačova slovníku, kde se objevuje dělení „Böhme“ či „Deutsch-Böhme“ ${ }^{8}$ Přesto národnostní rozdělení nemělo $\mathrm{v} 18$. století takovou důležitost, jakou mu později přiřklo národní obrození, do jehož prvopočátku lze zařadit i Dlabačovo dílo. Za dobový určující prvek by mohl být považován rodný jazyk, avšak ani ten se nedá chápat jako jediná rozlišovací charakteristika národní př́slušnosti v daném kontextu.

I přes problematickou terminologii a pramennou základnu zůstává tematika migrace hudebníků z českých zemí v 18. století stále přitažlivou pro badatele. Toho jsou důkazem již výše zmiňované práce. Ve snaze pojmout problematiku české hudební emigrace ve své celistvosti, a nejen s ohledem na důležité osobnosti, konkrétní destinaci či nástrojovou skupinu, nabídla Zdeňka Pilková statis-

6 PILKOVÁ, Z. Zur Frage der Musiker..., op. cit., s. 215. Blíže k dané termonilogii také PILKOVÁ, Zdeňka - VRKOČOVÁ, Ludmila - JEŘÁBEK, Richard. Migrace. In Slovník české hudební kultury. Jiří Fukač - Jiří Vysloužil - Petr Macek (eds.) Vyd. 1. Praha: Edition Supraphon, 1997, s 551-554.

7 PEČMAN, R. Rakušan Mysliveček?, op. cit., s. 70.

8 DLABACŽ, Gottfried Johann. Allgemeines historisches künstler-Lexikon für Böhmen und zum Theil auch für Mähren und Schlesien. Prag, 1815. Dlabačovo národnostní dělení hudebníků však není př́liš konsekventní a neodráží žádnou jasnou metodologii v tomto ohledu. 
tickou sondu založenou na nejvýznamnějším prameni pro studium hudební kultury v českých zemích v dané době, tj. na Dlabačově slovníku. ${ }^{9}$

Dlabačův slovník, tedy Allgemeines historisches künstler-Lexikon für Böhmen und zum Theil auch für Mähren und Schlesien, byl stěžejním dílem tohoto knihovníka premonstrátského kláštera na Strahově a zahrnuje v sobě 28 let detailní práce, podpořené rodícím se nadšením národního sebeuvědomění přelomu 18. a 19. století. Jeho autor se v něm snažil zdokumentovat všechny umělce pocházející z českých zemí, nebo v nich působící, a to od počátků až do autorovy současnosti. ${ }^{10}$ Nejpodstatněji jsou zde zastoupeni umělci právě z posledního období, tj. z průběhu 18. století. Pilková si pro svůj statistický přehled vybrala konkrétně časové období let 1740 až 1810.

Období druhé poloviny 18 . století bývá považováno za nejvýznamnější dobu s ohledem na pohyb hudebníků z českých zemí; migrační vlna však zasáhla v tomto období různé vrstvy obyvatelstva po celé Evropě, a jak podotýká Pilková, je třeba chápat výjimečnost tohoto období pro hudební dějiny pouze v rovině kvalitativní a nikoli kvantitativní. Fenomén migrace jako takové byl vždy přítomen $\mathrm{v}$ hudebních dějinách, i když v různých kontextech; migrace hudebníků $\mathrm{z}$ českých zemí $\mathrm{v}$ této době tak může být chápána do jisté míry jako paralela migrace vlámských hudebníků v 15. a 16. století a Italů v 17. a první polovině 18 . století. ${ }^{11}$ Kvalitní hudebníci z českých zemí působící v důležitých evropských hudebních centrech pak pravděpodobně stáli za obecně přijímaným názorem o výjimečné hudebnosti zdejších lidí, kterou zmiňuje již Charles Burney. ${ }^{12}$ Dochované prameny ani současné výzkumy však neumožňují relevantní posouzení úrovně hudebnosti obyvatel v českých zemích a její srovnání s ostatními evropskými zeměmi. Na otázku, jaký byl skutečný stav migrační vlny hudebníků pocházejících z českých zemí v 18. století, se pak pokouší nalézt odpověd' Pilková na základě Dlabačova slovníku.

Pro dané období, tedy druhou polovinu 18. století, zde nachází celkem 951 profesionálních hudebníků, z nichž 409 působilo po kratší či delší časové období $\mathrm{v}$ zahraničí. ${ }^{13} \mathrm{Z}$ tohoto počtu migrujících hudebníků se pak celých 360 usadilo v zahraničí natrvalo. Po odečtení hudebníků cestujících v rámci více zemí v průběhu kariéry udává Pilková také počty migrujících hudebníků s ohledem

9 PILKOVÁ, Z. Zur Frage der Musiker..., op. cit. a táž. Doba osvícenského absolutismu..., op. cit., s. 223-224.

10 První Dlabačem uváděné osobnosti pocházejí z 10. století.

11 PILKOVÁ, Z. Zur Frage der Musiker..., op. cit., s. 215.

12 BURNEY, Charles. Hudebni cestopis 18. věku. Praha: Státní hudební vydavatelství, 1966, s. 276-277.

13 Pojem ,zahraničíc “ Pilková vztahuje na veškeré území za hranicemi zemí Koruny české; statisticky tak mapuje jakýkoli známý pohyb mimo toto území, tj. včetně migrace do jiných částí habsburského soustátí i hlavního města Vídně. Při výpočtech migrace v rámci habsburského soustátí však zaměřuje svoji pozornost především na území současného Rakouska a blíže nerozlišuje migraci do různých italských center s ohledem na existenci či neexistenci jejich vazeb k habsburské monarchii. 
na jednotlivé destinace. Zjišt’uje tak, že takřka třetina hudebníků pocházejících z českých zemí působila $\mathrm{v}$ rámci jiných částí habsburského soustátí, nejčastěji pak v samotné metropoli Vídni. Druhou nejčastější destinací hudebníků byly oblasti severního a středního Německa, zejména města Drážd’any a Berlín. Další významnou migrační vlnu Pilková udává pro hudební centra carského Ruska, z nichž si hudebníci nejvíce volili carskou kapelu v Petrohradu. Podobného rozsahu byla také migrace do oblastí jižního Německa, kde se hudebníci uplatnili nejčastěji v kapelách ve městech Mannheim, Koblenz, Regensburg, Mainz, Donauenschingen a u švábského dvora v Öttingen-Wallersteinu. Poslední významnou destinací s ohledem na počet zde usazených hudebníků byly Uhry, zahrnující v dané době i území současného Slovenska. Ostatní země si pak, dle údajů z Dlabače, zvolilo méně než dvacet hudebníků: Slezsko (patřícího ovšem ve své celistvosti až do roku 1742 k zemím Koruny české), Francii, Polsko, Itálii, Anglii, Lužici, Švédsko, Belgii, Španělsko. Zvlášt' uvádí Pilková jednoho hudebníka, který se usadil ve svobodném městě Terstu, které však v té době patřilo do sféry habsburského soustátí. Jednotlivé jsou př́ípady hudebníků, kteří odešli mimo Evropu: do Č́ny, Indie, Mezopotámie či Jeruzaléma.

\begin{tabular}{|l|l|}
\hline Cílová země & Počet hudebníků \\
\hline Habsburské soustátí & 107 ( z nichž 79 ve Vídni) \\
\hline Severní a střední Německo & 69 \\
\hline Rusko & 44 \\
\hline Jižní Německo & 44 \\
\hline Uhry & 31 (z nichž 2 na území Slovenska) \\
\hline Slezsko & 19 \\
\hline Polsko & 15 \\
\hline Francie & 15 \\
\hline Itálie & 7 \\
\hline Anglie & 4 \\
\hline Lužice & 2 \\
\hline Švédsko & 2 \\
\hline Belgie & 2 \\
\hline Španělsko & 1 \\
\hline Mimo Evropu & 7 \\
\hline
\end{tabular}

Obr. 1. Tabulka jednotlivých destinací hudebníků na základě statistické studie Pilkové.

Pilková se ve své studii snaží o poměrně detailní statistický přehled migrace na základě údajů z Dlabačova slovníku, které doplňuje o další zdroje zaměřené na německé kapely; ${ }^{14} \mathrm{z}$ Dlabačova slovníku vypočtené množství hudebníků v jihoněmeckých kapelách (44) tak rozšiřuje na 55, z nichž 21 mělo být hráčů na lesní roh. Kromě přehledu četnosti migrace s ohledem na jednotlivé cílové

14 MURRAY, Sterling E. Bohemian Musicians in South German ,Hofkapellen“ during the Late 18th Century. Hudební věda, 1978, roč. 15, č. 2, s. 155-175, cit. dle Pilkové, viz pozn. č. 11. 
země se Pilková u Dlabače snaží nalézt odpověd' i na otázku sociálního rozvrstvení hudebníků v dané době. Vypočítává tak, že z 220 hudebníků zaměstnaných u šlechty jich celých 185 sloužilo u zahraničních dvorů; instrumentalistů, kteř́ nebyli vázáni na žádnou instituci a působili jako pedagogové a virtuózové, nalézá u Dlabače 89 , z nichž 67 působilo v zahraničí. Co se týče pozice kapelníků, nalézá Pilková 16 divadelních kapelníků, z toho 13 mimo území koruny české, dále 15 dvorních kapelníků, z nichž 14 mělo působit u dvorů mimo české země. U ostatních povolání pak tato studie vykazuje opačný poměr s ohledem na migraci: z 58 hráčů v divadelních orchestrech jich v zahraničí pobývalo jen 19, ze 79 chrámových hudebníků jen 3 a z 32 vojenských hudebníků jich mělo působit v zahraničí jen 5.

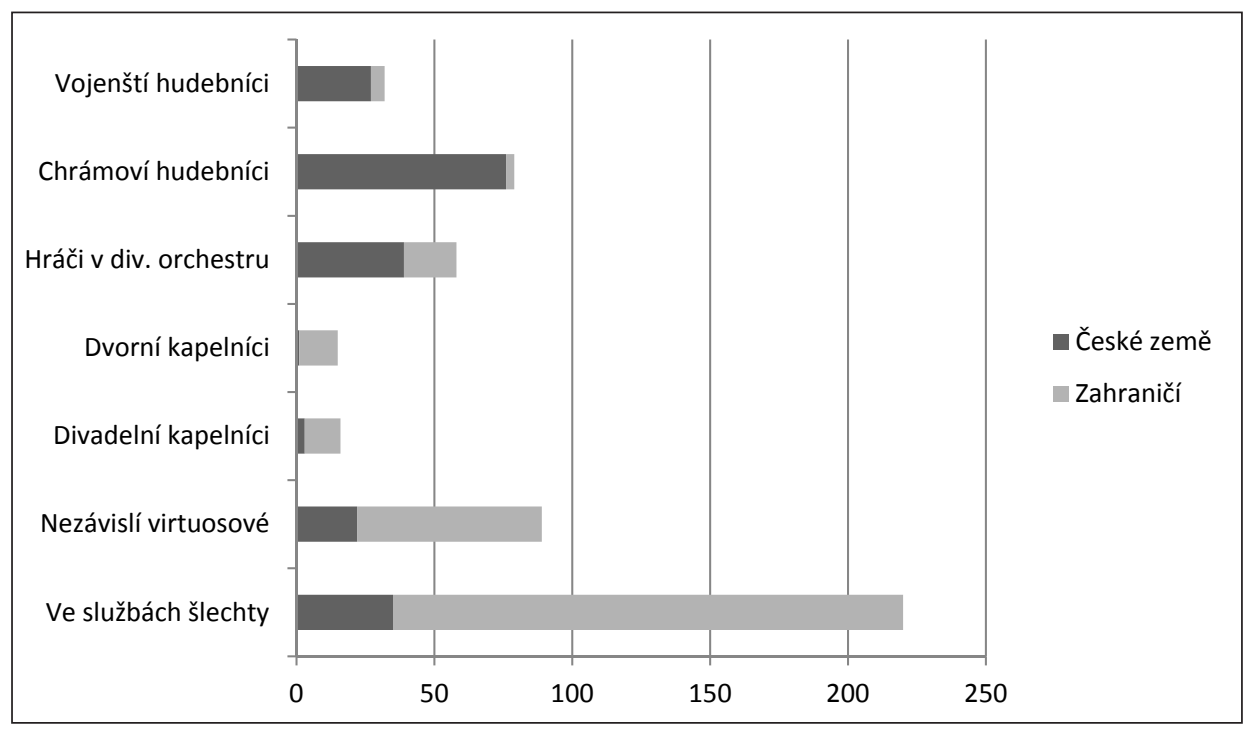

Obr. 2. Poměr hudebníků na různých pozicích v českých zemích a v zahraničí na základě statistické studie Pilkové.

Tyto detailní a dobově jistě velmi pracné statistické přehledy jsou cennou analýzou Dlabačova slovníku. ${ }^{15}$ Je však namístě zamyslet se, do jaké míry odrážejí skutečný rozsah migrace hudebníků pocházejících z českých zemí v dané době.

Pouhý letmý pohled na výsledky statistiky totiž vzbuzuje mnoho otazníků. Jedná se skutečně o obraz dobové situace, či pouze o doklad kvality a podmínek lexikografické práce Dlabačovy? Detailnější studium hesel vztahujících se k migrujícím hudebníkům a zejména zdrojových pramenů, které Dlabač ve své práci použil, staví totiž danou statistickou sondu do poněkud jiného světla. Již roku 1971 se Jiř́i Fukač pokusil o hloubkovou analýzu Dlabačovy lexikografické

15 Velké usnadnění práce s Dlabačovým slovníkem nabízí jeho elektronická verze s možností fulltextového vyhledávání, která vzniká na Ústavu hudební vědy MU v Brně. Její prozatímní verze je dostupná na: http://www.musicologica.cz/dlabac/ [cit. 23-02-2015]. 
metody, v níž si kladl mimo jiné otázku věrohodnosti obsahu slovníku také ze statistického hlediska. ${ }^{16}$

Ze samotného názvu Dlabačova slovníku je zřetelná jeho snaha podchytit v něm veškeré umělce z Čech, Moravy a Slezska. Již z předmluvy ke slovníku však vyplývá, že se ve skutečnosti zaměřil zejména na Čechy a pouze okrajově na Moravu a Slezsko. Fukač ve své analýze Dlabačovy metody blíže ukazuje, často $\mathrm{v}$ detailních číslech, skutečný obsah slovníku. Z celkového počtu 4469 slovníkových výstupů, z nichž má 4443 formu slovníkového hesla a 26 je poznámek, je jich jen minimum věnováno postavám z dávné minulosti; četnost popisovaných osob se značně zvyšuje postupem po časové ose. Většina hesel se pak zabývá umělci z 18. století. Dlabačovým cílem bylo zařadit do svého slovníku jakéhokoli umělce, u něhož znal jméno nebo alespoň jedno dílo. Pojem „umělec“ pak autor chápal $\mathrm{v}$ širokém dobovém kontextu, zahrnujícím také mnohá umělecká řemesla. Po boku hudebníků, malír̆u a sochařů, tak můžeme ve slovníku nalézt mistry stavitele, mědirytce, kamenorytce, stavitele hodin, brusiče skla, stavitele hudebních nástrojů, odlévače zvonů, či umělecké zahradníky („Kunstgärtner“). Celkovému počtu hesel ve slovníku však velmi významně nad ostatními uměleckými odvětvími dominují vstupy věnované hudbě. ${ }^{17}$ Pro Fukače má tato výrazná disproporce statistickou hodnotu, která sice nemusí přímo potvrzovat četnost hudebního povolání $\mathrm{v}$ daném prostoru, ale dokládá přinejmenším takovou četnost v pramenech, které Dlabač používal.

Fukač ve své studii představuje Dlabačův slovník z různých hledisek, částečně ilustrovaných četností jednotlivých jevů; odhaluje Dlabačovu nekritičnost s ohledem na výběr popisovaných osob a obsažnost jednotlivých hesel - mezi umělci se tak objevují i různí panovníci bez aktivního vztahu $\mathrm{k}$ hudbě, a rozsah hesla odpovídá spíše blízkosti dané osoby k autorovi, než jejímu objektivnímu významu; obsáhlost hesel je tak př́mo úměrná získaným informacím a dostatečně nereflektuje kvality daného umělce. $S$ ohledem na statistickou věrohodnost slovníku Fukač upozorňuje, že z jeho přehledu počtu hesel věnovaných hudbě nelze odvodit množství hudebníků ve slovníku, nebot' jednotlivá hesla v něm často zahrnují informace o více osobách najednou, mnohdy s rodinnými vazbami. Dlabačem důsledně udávané zdroje na konci jednotlivých hesel umožňují důkladnější zhodnocení jeho práce. Takové analýze podrobuje Fukač nejprve hesla vztahující se k starším obdobím, v nichž spatř̌uje odraz obtížné dostupnosti pramenů pro Dlabačovu práci a tudíž malou statisticky vypovídající hodnotu napsaných hesel. Jako statisticky věrohodná však Fukač vyzdvihuje hesla vážící se

16 FUKAČ, Jiří. Die Musiklexikographische Methode B. J. Dlabačs und ihre kunstgeschichtlichen Hintergründe. In Sborník praci filosofické fakulty brněnské university, Studia minora facultatis philosophicae universitatis brunensis, H 6 (1971), s. 63-86.

17 Fukač tento poměr opět dokládá přesnými čísly: 2919 (tj. 65,7\%) hesel věnovaných hudbě oproti 1524 (tj. 34,3\%) hesel zaměřených na ostatní citovaná odvětví. Co se týče územního rozvržení hudbě věnovaných hesel, většina se jich vztahuje k Čechám $(77,8 \%)$, množství hesel s vazbou k Moravě a Slezsku je pak podstatně menší (2,75\%, resp. 3,05\%), zbývající hesla (tj. 16,35\%) pak mají spojitost se zahraničím. FUKAČ, J., op. cit., s. 68. 
k období od Bílé hory po Dlabačovu současnost, pro jejichž sepsání si autor mohl posloužit množstvím dochovaných pramenů. Přesto i pro toto období nalézá, stejně jako u předešlých epoch, skupiny hesel, vytvořených na základě jednoho, poměrně nahodilého a statisticky nevypovídajícího pramene, které kvantitativní věrohodnost slovníku i pro dané období snižují. ${ }^{18}$ Přes zmíněné problematické skupiny hesel však považuje Fukač Dlabačův slovník pro svoji rozsáhlost, přesněji hesla vztahující se $\mathrm{k} 17$. a 18. století, za velmi důležitý pramen pro historické a lexikografické bádání, a to včetně otázky migrace hudebníků, které se však sám blíže ve své analýze nevěnuje.

Fukačovou pobídkou k dalšímu studiu Dlabačova slovníku se zřejmě nechala inspirovat Pilková pro své studie o migraci hudebníkủ. Rozširííme-li však Fukačovu metodu analýzy Dlabačových hesel i na otázku migrace, objeví se nutnost hlubšího kontextu statistických přehledů Pilkové. Dlabačova práce na slovníku byla zásadně ovlivněna dostupností informací z přímých a druhotných pramenů; tato skutečnost se pak musela o to více projevit ve vztahu $\mathrm{k}$ heslům o hudebnících působících mimo české země. Již v úvodním poděkování zmiňuje autor množství spolupracovníků a korespondentů z různých částí Evropy, kteří výrazně přispěli ke vzniku díla a z nichž mnohé uvádí jménem. Zaměříme-li se pak blíže na zdroje hesel o migrujících hudebnících v období 1740 až 1810, jak je vymezila Pilková, můžeme $\mathrm{z}$ nich vytvořit opět skupiny, které byly Dlabačovi zjevně sděleny stejným zdrojem. Takové rozdělení hesel umožňuje lepší posouzení sítě Dlabačových informátorů a tedy i statistickou hodnotu takto získaných údajů. Bližší analýza pak staví významnost jednotlivých destinací do jiného světla: statistická hodnota některých z nich se jeví méně podstatnou, naproti tomu jiné destinace byly zjevně autorem nedostatečně zmapovány, odtud jejich slabé zastoupení v rámci slovníku. ${ }^{19}$

Pro informace o hudebnících působících mimo české země byly pro Dlabače kromě bibliografických pramenů velmi podstatné zprávy od př́mých korespondentů a spolupracovníků. V rámci předmluvy ke svému slovníku cituje Dlabač jména hlavních z nich.

„[...] Herr Caspar Bauschek, regulierter Chorherr des Prämonstratenserstiftes Strahow in Prag, des Herzogs von Raudnitz Fürsten von Lobkowitz Bibliothekar, Doktor der Philosophie und Erzbischöflicher Notar; Herr Johann Peter Cerroni, k. k. Gubernialsekretär in Brünn [...] Herr Ignaz Cornova, Mitglied der königl. Gesellschaft dr Wissenschaften in Prag, [...] Herr J. L. Du-

Jedná se např́klad o skupinu 98 hesel vytvořených na základě Jahrbuch der Tonkunst von Wien und Prag (1796, 1797), pramene obsahujícího často velmi kusé informace, mnohdy o druhořadých hudebnících a hudebních amatérech z vyšších vrstev. Další skupina 11 hesel pak byla sepsána ze zkušebních protokolů studentů pražské univerzity, kteří byli roku 1749 „,veřejně přezkoušeni z praktické hudby“. Idem, s. 77.

19 Analýza zdrojů pro migraci hudebníků v Dlabačově slovníku, zejména ve vztahu k jeho síti spolupracovníků a informátorů, byla přednesena na kolokviu Entretiens sur la musique ancienne en Sorbonne, 9e édition, (7.-9. června 2012) pod titulem „Les cornistes en voyage ? Migration des musiciens originaires de Bohême au XVIIIe siècle : sources, typologie, itinéraires.“Akta z kolokvia se připravují pro zvláštní číslo časopisu Jardin de musique. 
ssik, Virtuos in London, dann in Paris, und sein Vater zu Cžaslau; Herr Engel, Organist an der katholischen Kapelle zu Leipzig; Herr Joseph Fiala, Virtuos in Berlin und Petersburg; Herr Kawka, Virtuos in Regensburg; Herr Klackel, Virtuos in Paris, dann in Prag; Herr Vincenz Kneer, Prior der Barmherzigen Brüder in Prag, ebenfalls ein virtuöser Baßsänger; Herr Alex Pařizek, k. k. Direktor der Normalschule in Prag, [...] Herr Wenzel Pichel, Erzherzoglicher Kapellmeister in Mailand, und dann zu Wien in Oesterreich; Herr Caspar Pilat, Schriftsteller und Provisor am Erzbischöflichen Seminarium in Prag; Herr Anton Pischely, ein würdiger Feldkapellan bei der k. k. Armee in Deutschland und Italien, hernach in Prag; Herr Gotthard Pokorný, Kapellmeister an der Kathedralkirche zu Brünn; Herr Ryba, Organist und Chorrektor zu Rožmital; Herr Schubert, kön. Hofvirtuos in Dresden; Herr Johann Bapt. Waňhall, Komponist und Virtuos in Wien [...] ]“20

Takto představení spolupracovníci ukazují nejen na převahu hudebně znalých, ale také na geografické rozmístění informátorů, v němž jsou zastoupena hlavní evropská kulturní centra: Londýn, 2x Pař̌́ž, 2x Vídeň, Petrohrad, Lipsko, Berlín, Regensburg, Drážd’any a Miláno. I když taková sít korespondentů může nabízet dostatečné pokrytí daných lokalit, nebyla ve skutečnosti spolupráce všech v předmluvě jmenovaných stejně rozsáhlá, jak lze alespoň vyčíst z hotových slovníkových hesel. Navíc Dlabačův výčet spolupracovníků není vyčerpávající. Jaké tedy byly Dlabačovy zdroje pro hesla o migrujících hudebnících?

Ze statistického přehledu Pilkové se ukazuje jako nejpočetnější migrační vlna směrem do hlavního města monarchie Vídně, stejně jako do dalších oblastí Rakouska. Takový výsledek je zcela logicky předvídatelný. Dalo by se však předpokládat, že právě pro tuto destinaci měl i Dlabač nejsnazší př́stup k pramenům. Ve skutečnosti jsou ale hesla o zde působících hudebnících čerpána zejména z bibliografických pramenư ${ }^{21}$ a pouze $\mathrm{v}$ menší míře se zde objevují odkazy na př́mé a nepř́mé informátory. ${ }^{22}$ Některé hudebníky pak Dlabač ve Vídni osobně potkal, a to, jak sám nejčastěji uvádí, v červenci roku 1795. I přes zdánlivou úplnost těchto hesel a pravděpodobný snadný př́stup $\mathrm{k}$ informacím, však ve slovníku nenalezneme všechny z jiných pramenů známé hudebníky. ${ }^{23}$

Druhá nejvýznamnější migrační vlna hudebníků, směrovala do německých center. I zde vysoké počty z českých zemí pocházejících hudebníků nepřekvapí vzhledem ke geografické blízkosti Německa a tradičním stykům mezi Prahou

20 DLABACŽ, op. cit., s. xi-xii.

21 Jedná se zejména o MEUSEL, Johann Georg. Teutsches Künstlerlexikon; oder, Verzeichniss der jetztlebenden Teutschen Künstler. Lemgo: Meyerschen Buchhandlung, 1808; GERBER, Ernst Ludwig. Historisch-Biographisches Lexicon der Tonkunstler. Leipzig: Johann Gottlob Immanuel Breitkopf, 1790; periodikum Vaterländischen Blätter für den österreichischen Kaiserstaat, Wien, 1808-1814 a Dlabačovy vlastní výzkumy v rámci DLABACŽ, G. J. Versuch eines Verzeichnisses der vorzüglichen Tonkünstler in oder aus Böhmen. In Materialien zur alten und neuen Statistik von Böhmen. Rieger, J. A. (ed.), Leipzig - Prag, seš. 7, 1788, s. 133-162, seš. 12, 1794, s. 225-298.

22 Důležitým informátorem nejen pro Vídeň byl Václav Pichl, zejména pak jeho dopis z 18. ř́ijna 1803 adresovaný Dlabačovi. Dále hudebníci Jan Křtitel Kuchař, či Václav Tomáš Matějka.

23 Jedná se o některé hudebníky ve schwarzenberských službách, ale i o členy dvorské císařské kapely. 
a nedalekými centry, Drážd’anami a Berlínem. Také Dlabačova sít' korespondentů, u nichž zmiňuje německá města, je nejpočetnější. Míra jejich př́mé spolupráce na slovníku však není jednoznačně zjistitelná. V Lipsku působící varhaník Engel dle našich zjišstění není citován u žádného z hesel a dokonce ani on sám své heslo ve slovníku nemá. Další jmenovaný, Josef Fiala, má u svého jména zpřesnění, že byl virtuosem v Berlíně a Petrohradu. V rámci jeho cestovatelsky nabité hudební kariéry však tato dvě města nehrála hlavní úlohu: v Petrohradě působil u prince Orlova (1786-1790ca), do Berlína pak zavítal v rámci koncertního turné začátkem 90 . let 18. století. Nejdelší část svého života totiž působil na různých německých dvorech. I přes pro Dlabače velký potenciál tohoto informátora, není jeho spolupráce př́liš zřetelná. Kromě obsáhlého hesla k jemu samému se Fiala objevuje jako zdroj pouze u tř́ dalších hudebníků, z nichž jeden působil ve Varšavě a další dva odcestovali do Ruska. ${ }^{24}$ Ani spolupráce $s$ dalším jmenovaným hudebníkem z Německa není v Dlabačově slovníku jednoznačně postř̌ehnutelná. V Drážd'anech působící houslista Josef Schubert totiž není citován u žádného hesla. Pouze u jednoho hesla je pak jmenován další korespondent, houslista Josef Kafka z kapely Thurn-Taxisů v Regensburgu. ${ }^{25}$ Ani předvídatelně velká migrace hudebníků z českých zemí do různých oblastí Německa tedy nebyla pro Dlabače snadno zmapovatelnou. Posun oproti informacím z novodobých studí a z Dlabače získaných počtů migrujících hudebníků uvádí Pilková pro oblasti jižního Německa v hodnotě $25 \% .{ }^{26}$ Lze se domnívat, že i u dalších německých destinací byl skutečný počet zde působících hudebníků původem z českých zemí podstatně vyšší, než jak lze vyčíst z Dlabačova slovníku.

Vedle zcela předvídatelných četných destinací pro migrující hudebníky na území Německa se ve statistickém přehledu Pilkové objevuje také již překvapivější carské Rusko. Zde mělo být dle Pilkové roku 1796 v carské dvorní kapele v Petrohradě z 34 členů minimálně 12 pocházejících z českých zemí. Dlabač však uvádí dle našich zjištění dokonce 50 hudebníků, kteří odcestovali do Ruska, celých 35 z nich pak působilo v poslední třetině 18 . století v carské kapele v Petrohradu. Hesla vztahující se u Dlabače k hudebníkům působícím v Rusku zahrnují většinou poměrně krátký časový úsek přibližně mezi léty 1780 a 1800; pro podstatnou část z nich pak byl zdrojem informací Ignaz Foyta, houslista působící v carské kapele v letech 1778 až 1798, který se na důchod vrátil do Prahy. ${ }^{27}$ Vyvstává tedy otázka, do jaké míry je s ohledem na ostatní destinace poměrně vysoký počet ve slovníku zmíněných migrujících hudebníků do Ruska výsledkem kvalitních

24 Hesla: „Č̌ermák“ (DLABACŽ 1815, op. cit., Bd. I, sl. 306), „Wanzura, Ernest“ (DLABACŽ 1815, op. cit., Bd. III, sl. 333-334), „Wrba“(DLABACŽ 1815, op. cit., Bd. III, sl. 419-420).

„Hanisch“ (DLABACŽ 1815, op. cit., Bd. I, sl. 551).

Viz pozn. č. 14.

Hesla, jejichž zdrojem byl Ignaz Foyta, zároveň znamenají největší skupinu hesel získaných od jednoho informátora pro jednu destinaci. Jeho jméno je uvedeno u 14 hesel o celkem 17 hudebnících, $11 \mathrm{z}$ nich působilo v carské kapele $\mathrm{v}$ Petrohradu. Lze se domnívat, že byl informátorem $\mathrm{k}$ většímu počtu hesel, než u nichž je přímo citován. Zejména s ohledem na časové období působení hudebníků v Petrohradu. 
informátorů, či jak dalece měla tato destinace skutečně významné postavení. Dlabač nám neusnadňuje bádání s ohledem na dřívější období, je tedy také možné, že vyšší frekvence českých hudebníků na tomto území ke konci 18. století souvisela s působením konkrétních osob, které za sebou přilákaly další rodáky. ${ }^{28}$

Překvapení zcela opačného rázu vytváří Pilkovou nalezených pouhých sedm hudebníků z českých zemí, kteří měli působit v Itálii. Italská hudba měla v tomto období významné postavení ve střední Evropě a pro studijní cesty hudebníků byla tato země hlavní destinací. Je tedy zarážející, že ve statistickém přehledu je počet migrujících hudebníků do Itálie nižší než například do Francie (15). Významným zdrojem pro Dlabače ohledně v Itálii působících hudebníků byl již dříve zmíněný Václav Pichl, který v letech 1777 až 1796 působil jako kapelník $\mathrm{u}$ arcivévody Ferdinanda v Miláně, poté pak ve Vídni. Jen z hesel vytvořených částečně, či zcela na základě dopisu, který Pichl Dlabačovi roku 1803 zaslal, se nám však podařilo nalézt minimálně 17 hudebníků z českých zemí, působících v Itálii, z toho patnáct na územích mimo sféru habsburského soustátí. Celkový počet zde žijících hudebníků však musel být ještě podstatně větší. Detailnější informace o těchto hudebnících by se pravděpodobně daly získat ze spisu, který dle Dlabače Pichl připravoval, avšak který se nedochoval. ${ }^{29}$

S ohledem na př́stupnost informací byla pro Dlabače problematickou zřejmě i migrace hudebníků do Francie. Hesla o Pilkovou napočítaných patnácti hudebnících pocházejí až na malé výjimky z bibliografických pramenů..$^{30} \mathrm{~V}$ úvodu slovníku Dlabač zmiňuje Paříž, jako jedno z působišst', u dvou informátorů, kterým zde děkuje: Jana Ladislava Dusíka a Štěpána Klackela. Přestože se nám nepodařilo nalézt hesla, u nichž by byla jejich spolupráce jednoznačně uvedena, ${ }^{31}$ lze se domnívat, že Dlabačovi byli s průzkumem v Paříži působících hudebníků nápomocni. Tak tomu zřejmě bylo např́klad u hesla „Maschmehr, Prokop Martin“, u nějž se Dlabač odvolává na blíže nespecifikovanou korespondenci. V rámci hesla je pak uvedeno, že měl být hudebník, ,ještě roku 1788“"v Paříži. Zmíněný časový údaj však spadá právě do období přibližně dvouletého pařížského pobytu Jana Ladislava Dusíka.

Z rozboru hesel Dlabačova slovníku vztahujících se $\mathrm{k}$ alespoň hlavním destinacím pro migrující hudebníky z českých zemí vyplývá nutnost hlubšího kontex-

28 V tomto smyslu mohl např́iklad působit i zmiňovaný Josef Fiala, který byl v letech 17861790ca angažován v Petrohradě u prince Orlowa, aby mu zbudoval vlastní kapelu.

29 Dle Dlabače při dobývání Lombardie Francouzi (1796) Pichlovy „,musikalische Büchersammlung, wie auch eine Geschichte der böhmischen Tonkünstler in Italien, die er selbst fleißig verfaßt hatte“ padly do rukou dobyvatelů. Viz DLABACZ, op. cit., heslo „Pichel, Wenzel".

30 Výjimkou je například heslo „Wondráczek, Franz“o virtuosovi na kladívkový klavír pocházejícím z Prahy, který působil od roku 1760 v Paříži a zde také zemřel (1781). Informace o něm Dlabač získal z blíže neurčené korespondence a ze zprávy od jistého Franze Heidela, který se s Vondráčkem roku 1767 v Pařriži setkal.

31 Pouze Klackela jsme nalezli v rámci hesel „Vit, Gregor“" a „Kolbe, Anton“, kde figuruje jako učitel, potažmo žák hry na housle. Ani jedno z těchto hesel však nemá vazbu k Francii. 
tu jakékoli statistiky vytvořené na jeho základě. Dlabačův slovník, i přes velmi důkladnou a soustavnou práci svého autora, $\mathrm{v}$ sobě odráží problémy rodící se lexikografie, at' $\mathrm{v}$ rovině metodologické, či jen pouhé obtížnosti př́istupu $\mathrm{k}$ informacím. I když se tento slovník jeví jako zcela zásadní pramen pro hudební dějiny českých zemí zejména $\mathrm{v} 18$. století, jeho nedostatky vyvstávají hlavně při snahách o jeho použití ke statistickým účelům. ${ }^{32}$

Přestože se Dlabačův slovník jeví jako problematický pramen pro kvantitativní studie bez použití dalších pramenů, zůstává nenahraditelným zdrojem informací kvalitativních. Díky množství jím uvedených hudebníků s mnohdy velmi detailními informacemi, $\mathrm{v}$ některých případech pocházejícími př́mo z první ruky nebo od současníků či rodinných príslušníků, nabízí se tento pramen jako zajímavý zdroj pro typologickou sondu o migrujících hudebnících. Zjišt’ujeme tak, že migrující hudebník pocházel často z minimálně druhé generace muzikantů a dostalo se mu tedy od útlého mládí kvalitního hudebního vzdělání, významnou roli na takovém vzdělání měly i řádové školy a gymnázia; české země opouštěl přibližně mezi 20 a 30 rokem svého života bud' pro zdokonalení se u mistra v nějakém z evropských hudebních center, či již do prvního angažmá; odchod do zahraničí pak mohl být spojen i s nedovoleným opuštěním služby. Výjimkou nejsou v Dlabačově slovníku ani řádoví hudebníci migrující v rámci své služby. Co se týče nástrojových preferencí, nalézáme mezi migrujícími hudebníky nejčastěji hráče na strunné a dechové nástroje, dále pak také na nástroje klávesové; hráči na drnkací nástroje, jsou spíše výjimkou. Hráči na lesní roh, jejichž umění bývá nejčastěji s migrujícími hudebníky z českých zemí v 18. století spojováno, však alespoň v rámci Dlabačova slovníku netvoří hlavní nástrojovou skupinu. ${ }^{33}$

Jana Franková (jana_frankova@seznam.cz), Université de Paris - Sorbonne, Paris IV. a Ústav hudební vědy, Filozofická fakulta, Masarykova univerzita, Brno.

\section{ABSTRACT \\ THE MYTH OF “CZECH MUSICAL EMIGRATION" VIEWED THROUGH THE DLABACZ'S DICTIONNARY}

The term of "Czech musical emigration" was subject to studies of numerous scholars during the history of the Czech musicology, regardless the anachronism of such an appellation. Gottfried Johann Dlabacž and his major work, Allgemeines historisches künstler-Lexikon für Böhmen und zum Theil auch für Mähren und Schlesien, (Prag 1815), represents the principal source of information

32 To dokazují zejména Pilkovou vyrobené přehledy typologie zaměstnání hudebníků, v nichž výrazný nepoměr mezi počtem kapelníků působících doma a $\mathrm{v}$ zahraničí a počtem běžných hráčů $\mathrm{v}$ orchestru doma a v zahraničí zřetelně odráží spíše ztížený přístup $\mathrm{k}$ informacím o běžných hráčích v zahraničí než jejich tak výrazně nižší uplatnění mimo české země oproti kapelníkům.

33 FITZPATRICK, Horace. The Horn and Horn-playing and the Austro-Bohemian tradition from 1680 to 1830. London: Oxford University Press, 1970. 
about musicians living or coming from the Czech lands, especially during the $17^{\text {th }}$ and $18^{\text {th }}$ centuries. The uniqueness of such a compendium of information led also to its use as a material for study of the "Czech musical emigration", comprising statistic studies based on it. Nevertheless, a detailed analysis of Dlabacz's dictionary regarding migrating musicians in the $18^{\text {th }}$ century reveals numerous questions. How did Dlabacz collect information? What can we conclude from such an analysis regarding migrating musicians? How relevant is the quantitative aspect of particular destinations? Is Dlabacz's dictionary statistically relevant at all?

Detailed analysing the network of Dlabacž's collaborators and correspondents helps to better understand the amount of articles in the dictionary in relation to musicians from the Czech lands working in different European destinations. Dlabacž's work was considerably influenced by the access to sources and information on musicians. This was even more difficult when concerning musicians working abroad. It is thus evident that any statistic analysis of this rich information source needs a contextualisation and merely represents an analysis of the dictionary in relation to the migration of musicians than reflects the real situation in the field.

Even if a quantitative analysis of the Dlabacž's dictionary remains problematic, we can find there much important information. A survey of biographies and careers of migrating musicians thus permit us to set up their typology.

\section{Key words}

Czech musical emigration, migration of musicians in the $18^{\text {th }}$ century, lexicography of music, G. J. Dlabacz

\section{Bibliography}

BAČVAROVÁ, Radmila. Mozartův pařižský př́tel a editor: Český trubač František Josef Hejna. Hudební věda, 1991, roč. 28, č. 4, s. 308-313.

BORKOVÁ, Alena. K problematice české emigrace 18. století - J. Vaňhal. Opus musicum, 1971, roč. 3, č. 9-10, s. 285-291.

BURNEY, Charles. Hudební cestopis 18. věku. Praha: Státní hudební vydavatelství, 1966.

DLABACŽ, Gottfried Johann. Versuch eines Verzeichnisses der vorzüglichen Tonkünstler in oder aus Böhmen. In Materialien zur alten und neuen Statistik von Böhmen. Rieger, J. A. (ed.), Leipzig - Prag, seš. 7, 1788, s. 133-162, seš. 12, 1794, s. 225-298.

DLABACŽ, Gottfried Johann. Allgemeines historisches künstler-Lexikon für Böhmen und zum Theil auch für Mähren und Schlesien. Prag, 1815.

FREEMAN, Daniel E. Josef Mysliveček, „Il boemo": the man and his music. Sterling Heights, Michigan: Harmonie Park Press, 2009.

FREEMANOVÁ, Michaela. Provincia germanica řádu milosrdných bratří. K pohybu hudebníků v českých zemích a střední Evropě 18. a 19. století. Hudební věda, 1998, roč. 35, č. 2, s. 171-174.

FUKAČ, Jiř́i. Die Musiklexikographische Methode B. J. Dlabačs und ihre kunstgeschichtlichen Hintergründe. In Sbornik praci filosofické fakulty brněnské university, Studia minora facultatis philosophicae universitatis brunensis, H 6 (1971), s. 63-86.

GERBER, Ernst Ludwig. Historisch-Biographisches Lexicon der Tonkunstler, welches Nachrichten von dem Leben und Werken musikalischer Schriftsteller, berühmter Componisten, Sänger, Meister auf Instrumenten, Dilettanten, Orgel-und Instrumentenmacher, enthält. Leipzig: Johann Gottlob Immanuel Breitkopf, 1790.

HELFERT, Vladimír. Jiři Benda: Přispěvek k problému České hudebni emigrace. Brno: Filosofická fakulta, I. sv., 1929, II. sv., 1934.

KABELKOVÁ, Markéta. Wenzel Johann Tomaschek, nebo Václav Jan Tomášek? - Německy mluvící Čech aneb život na hranici dvou jazyků. Hudební věda, 2009, roč. 46, č. 4, s. 341-354. 
MACEK, Petr. František Xaver Richter 1709-1789. Holešov, Město Holešov: Knihovnička Holešovska sv. 19, 2009.

MEUSEL, Johann Georg. Teutsches Künstlerlexikon; oder, Verzeichniss der jetztlebenden Teutschen Künstler. Nebst einem Verzeichniss sehenswürdiger Bibliotheken, Kunst- Münz- und Naturalienkabinete in Teutschland und in der Schweitz. Lemgo: Meyerschen Buchhandlung, 1808.

PEČMAN, Rudolf. Josef Mysliveček. Praha: Editio Supraphon, 1981.

PEČMAN, Rudolf. Rakušan Mysliveček? Hudebni véda, 1998, roč. 35, č. 1, s. 68-71.

PILKOVÁ, Zdeňka. Doba osvícenského absolutismu (1740-1810). In Hudba v českých dějinách. Jaromír Černý - Vladimír Lébl - Jan Kouba et al. (eds.), 2. dopl. vyd. Praha: Supraphon, 1989, s. 211-284.

PILKOVÁ, Zdeňka. Hudebníci z českých zemí v 18. století na drážd’anském dvoře. Opus musicum, 1992 , roč. 22, č. 2, s. 51-57.

PILKOVÁ, Zdeňka. Böhmische Musiker am Dresdner Hof zur Zeit Zelenkas. In Zelenka-Studien I, 1993, s. 55-64.

PILKOVÁ, Zdeňka. Zur Frage der Musiker aus böhmischen Ländern, die im Ausland wirkten, 1740-1810. In Telemanniana e talia musicologica: Festschrift für Günter Fleischhauer zum 65. Geburtstag. Dieter Gutknecht - Hartmut Krones - Friedrich Zschoch (eds.). Oschersleben: Ziethen, 1995, s. 215-220.

PILKOVÁ, Zdeňka. Zelenkas Zeitgenossen und Nachfolger aus Nordböhmen in der Dresdner Hofkapelle. In Zelenka-Studien II, 1997, s. 487-492.

PILKOVÁ, Zdeňka - VRKOČOVÁ, Ludmila - JEŘÁBEK, Richard. Migrace. In Slovník české hudebni kultury. Jiří Fukač - Jiří Vysloužil - Petr Macek (eds.) Vyd. 1. Praha: Edition Supraphon, 1997, s 551-554. 
